\title{
"Habak Al-Madinah Al-Munawarah"; (Ocimum Basilicum) Endophytic-ability against Pathogenic-bacteria Proven Success- use-constantly in Saudi-society, Taif, KSA
}

\author{
Sherifa Mostafa M. Sabra ${ }^{{ }^{*}}$, Afaf Bushara M. Ismail ${ }^{2}$ \\ ${ }^{1}$ Corresponding Author, Senior Const., Asst. Prof., Dr., Specialty Microbiology \\ ${ }^{2}$ Asst. Prof., Analytical Chemistry Specialty \\ ${ }^{1}$ Microbiology Br., Biology Dept., Science College, Taif University, KSA \\ ${ }^{2}$ Med. Laboratory Dept., App. Med. Sci. College, Taif University, KSA \\ ${ }^{1}$ Serology Unit and Bacterial Strains Bank, [AHRI], Dokki, [ARC], Giza, Egypt \\ ${ }^{2}$ Chemistry Dept., Sci. College, Al-Dalanj University, Sudan
}

*Corresponding Author: Sherifa Mostafa M. Sabra, Senior Const., Asst. Prof., Dr., Specialty Microbiology, Micro. Br., Biology Dept., Sci. College, Taif University, KSA, Egypt.

\begin{abstract}
This work was first time for "Habak Al-Madinah Al-Munawarah"; (Ocimum basilicum) (OB) endophytic-ability against pathogenic-bacteria $(P B)$ proven success-use-constantly $(S U C)$ in Saudi-society (SS), Taif, KSA". Through in-vitro, experiment had found Fungi endophytic crude extracts (FECEs)had eliminated Gram-positive (GP-PB), and Gram-negative (GN-PB). Actinomyces endophytic crude extracts (AECEs)were stronger, eliminating GP-PB and GN-PBthan FECEs. Colony Forming Unit (CFU)/ml found through in-vitroexperiment the growth colonies number were more effective by AECEs than FECEs to kill PB that could lead to SSinfectious diseases. The characteristics of OBis a plant preserves endophyte microorganisms (MOs) and kills $P B$ in a very vital bio-bactericidal way. It is available and cheap price. The results confirm OBproven SUC in SS and athigh altitude area (HAA).As the use in food and beverages because of their medical importance in maintaining public health (PH).That decided endophytes present in OBare of medicinal and therapeutic significance as they included Fungi and Actinomycetes. They are secreting substances capable of killing PB by bio-bactericidal way. Therefore, it is using in KSA, but the current in-vitroexperiment has used at HAA and proved highly effective to kill PB that might lead to infection disease, which maintains PH.This concluded OBendophytes proved its bio-bactericidal effects to kill PB. AECEs were stronger thanFECEs at HAA. OBrecommended using in beverages and foods without boiling prevent killingendophytes MOs and kept its bio-bactericidal effects to kill PB. This provenSUC in SS and at HAA helps maintain PH.
\end{abstract}

Keywords: Habak Al-Madinah Al-Munawarah, Ocimum basilicum, Endophytic-ability, Pathogenic-bacteria, Saudi-society, In-vitro experiment.

\begin{tabular}{l} 
ABBREVIATIONS \\
\begin{tabular}{|c|c|c|c|c|c|}
\hline $\begin{array}{c}\text { Actinomyces } \\
\text { endophytic crude } \\
\text { extracts: } \text { AECEs }\end{array}$ & $\begin{array}{c}\text { Fungi endophytic } \\
\text { crude extracts: } \\
\text { FECEs }\end{array}$ & $\begin{array}{c}\text { High-altitude-area: } \\
\text { HAA }\end{array}$ & $\begin{array}{c}\text { Ocimum basilicum: } \\
\text { OB }\end{array}$ & $\begin{array}{c}\text { Public-health: } \\
\text { PH }\end{array}$ & $\begin{array}{c}\text { Streptococcal } \\
\text { pyogenes: } \text { SP }\end{array}$ \\
\hline $\begin{array}{c}\text { Colony Forming } \\
\text { Unit: } \text { CFU }\end{array}$ & Gram-negative: GN & Klebseilla & $\begin{array}{c}\text { Pathogenic- } \\
\text { bacteria: } P B\end{array}$ & $\begin{array}{c}\text { Staphylococcous } \\
\text { aureus: } \text { SA }\end{array}$ & Saudi-society: SS \\
\hline $\begin{array}{c}\text { Escherichia coli: } \\
\text { EC }\end{array}$ & Gram-positive: & Microorganisms: & $\begin{array}{c}\text { Pseudomonas } \\
\text { aeruginosa: } \text { PA }\end{array}$ & $\begin{array}{c}\text { Staphylococcous } \\
\text { epidermidis: } \text { SE }\end{array}$ & Success-use- \\
constantly: SUC
\end{tabular} \\
\hline
\end{tabular}

\section{INTRODUCTION}

"Habak Al-Madinah Al-Munawarah"; $O B$ used to SUC in SS; leaves possess strong endophytes have antibacterial activities [1].That considered bio-antibacterial potential materials, there are two famous common fundamental MOs groups asendophytes, are include Fungi and Actinomyces; have antibacterial activity against more PB, which induce infectious diseases [2].

Endophytic Fungiyield special stimulated metabolites [3], include terpenoids [4], alkaloids [5], 4Chloro-benzenesulfonamide and N-methyl, that all have antibacterial properties [6] Fourteen Fungal 
"Habak Al-Madinah Al-Munawarah"; (Ocimum Basilicum) Endophytic-ability against Pathogenicbacteria Proven Success-use-constantly in Saudi-society, Taif, KSA

endophytes were isolated from $O B$ leaves, included Aspergillus, Ascochyta, Nigrospora, Blastomyces, Colletotrichum, Exidia, Clitopilus and Nomuraea. FECEs had tested against PB were included SA, $S E, E C, K P$ andPA. All FECEs showed grades of antibacterial activity, Nigrospora MFLUCC16-0605 showed broad-spectrum, indicated endophyticbio-active power that has a strong bio-antibacterial activity [7].

Endophytic Actinomyces has specially Streptomyces flavovirdis A3WK as famous [8], their products include phenols, carboxylic acid and alkanes have potent antibacterial properties [9].The bioactivity power of AECEs had antibacterial activity against hospital PB. Antibiotic creating having broadspectrum bactericidal activity [10].1H-pyrazole-3-carboxylic acid-5- methyl [11], pyrazol-5carboxylic acid-3-methyl, tri-fluro-acetoxypentadecane, propionic acid, 3-(maminobenzoyl)-2methyl-, 2,6-octadiene,2,6-dimethyl and 1Methyl-3-nitro-5[4-nitropyrazole-1-yl]has double antibacterial activity [12]. AECEs were basis of antibacterial activity that gives plant medicinal price. Eleven endophytic Actinomycetes were isolated, 12 compounds revealed Streptomyces flavovirdis A3WK has more antibacterial action. AECEs had tested against PB included extremely PB revealed as antibacterial inhibitory activity [13].

This research had carried out in an aim of Taif region experiment, which is one of HAA in KSA and has characteristics distinct from the normal area. Anin-vitroexperiment had made to "Habak AlMadinah Al-Munawarah", $O B$ endophytic-ability against PB proven SUC in SS, Taif, KSA. Endophytes is natural products in plants, can kill PB. FECEs and AECEs had tested against more PB. The results were followed relationship between them and PB for 11 hours. That might be proving the ability of ECEs to capable until which extent to kill PB. This could help to maintain PH at HAA, which by using natural plants. $O B$ contains the capabilities to kill more PB in a very vital and very cheap ways and is still a habit of SS since long ancients.

\section{Methodology}

2.1. Sample Collections: Farms-owners agreement on research had obtained. $O B$ plant leaves had collected from organic farms. The leaves had collected from medium sized healthy plants in closed sterile polythene bag. That had labeled and had brought to "Bacteriological Laboratory" within 24 hours [14].

2.2. Samples Preparation: Leaves had washed gently under running tap water, had cut into parts $(0.5-1 \mathrm{~cm})$, had dipped in $70 \%$ ethanol for 5 seconds then by $4 \%$ sodium hypochlorite for 90 seconds. Then they had rinsed in sterile distilled water for 10 seconds. The excess moisture had tarnished in sterile filter paper [15].

2.3. Extracts Preparation: The surface sterilized parts had placed in Fungi medium, had incubated at $28^{\circ} \mathrm{C}$ for 3 days [14].FECEs had obtained by Ethyl Acetate [16]. On the other side the surface sterilized segments had placed in Actinomyces medium, had incubated at $28^{\circ} \mathrm{C}$ for (3-4) weeks [17].AECEs had obtained by Ethyl Acetate [18]

2.4.In-Vitro Experiment: Obtained classified PB isolates had got from "Research Center"; appropriate environments had improved for PB growth. PB had tested into GP included ( $S A, S E$ and $S P$ ); GN included (EC, $P A$ and $K P$ ) [19]. Sterile screw capped tubes had used; put $5 \mathrm{ml} \mathrm{ECE} \mathrm{+}$ $5 \mathrm{ml}$ of PB suspension $\left(10^{3}-10^{4} / \mathrm{ml}\right)$, then had mixed for each ECE separately. Tubes had incubated at (35-37) ${ }^{\circ} \mathrm{C}$, and the experiment had followed up. One ml had taken from each tube in the following time $(0,1,3,5,7,9$ and 11) hours. They were cultured on PB appropriate media; they had incubated for 48 hours at $(35-37)^{\circ}$ C. Growth colonies had recorded [20]. Developed colonies mean had calculated by "Law Equation: CFU / ml = (Colony count / 300) X 100". The mean rates of reducing growth colonies amount had followed-up [21].

2.5. Data Analysis: "Simple Basic Excel Formulas" had cast-off method the results data [22]. 
"Habak Al-Madinah Al-Munawarah"; (Ocimum Basilicum) Endophytic-ability against Pathogenicbacteria Proven Success-use-constantly in Saudi-society, Taif, KSA

\section{RESULTS AND DISCUSSION}

Table1 and graph1: Mean of bacterial growth based on inoculation time

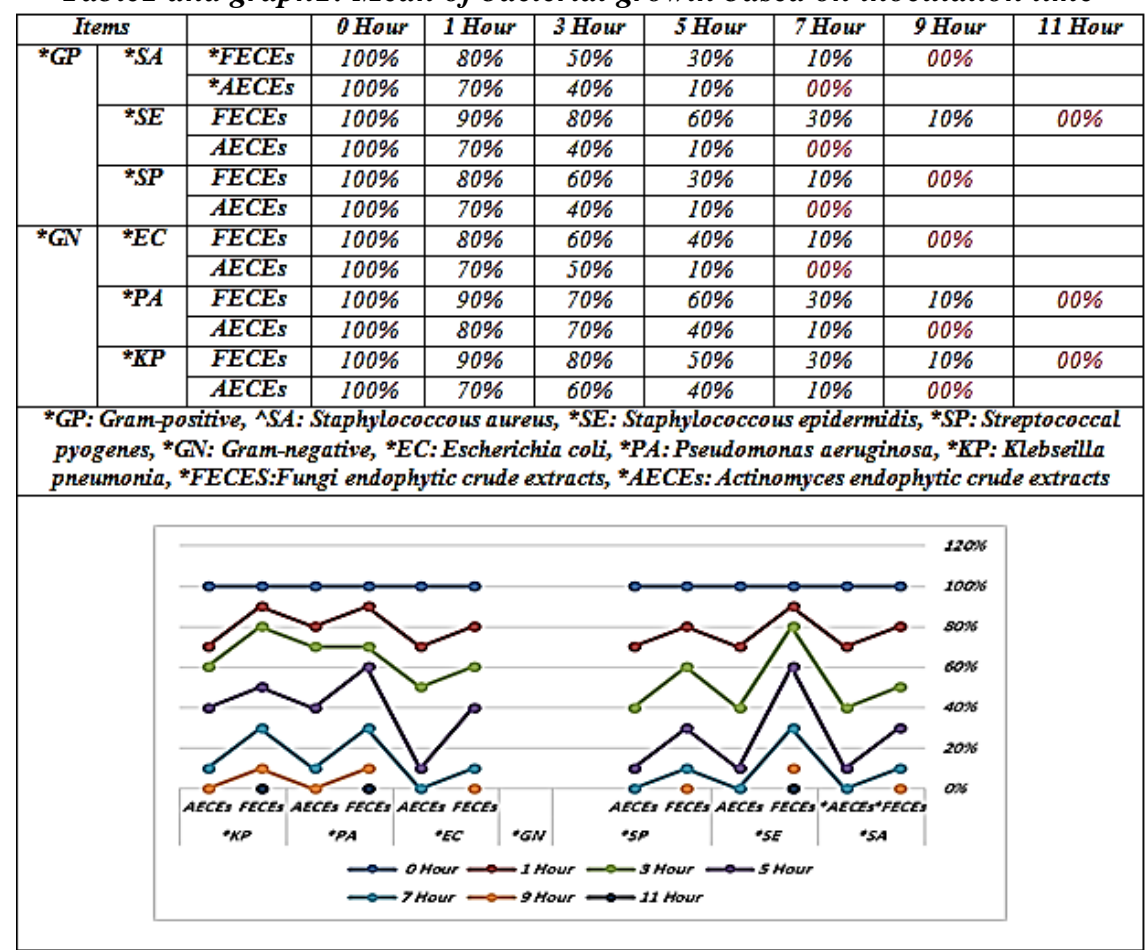

Table 1 and graph 1 revealed mean of bacterial growth based on inoculation time, because of an in-vitro experiment, it had found products of endophytes MOs were able to kill PB by varying degrees. It had found that FECEs had eliminated the GP-PB, and GN-PB [3-7]. Nevertheless, AECEs were stronger, eliminating the GP-PB in less time than FECEs, also in the GN-PB. That indicated the ability of AECEs stronger than FECEs [8-13]. That all had indication the effect of endophytes MOs on PB, which revealed protection role, that was sign in proven SUC in SS at HAA, Taif, KSA [1-2].

Table2 and graph2: Mean of bacterial *CFU/ml based on inoculation time

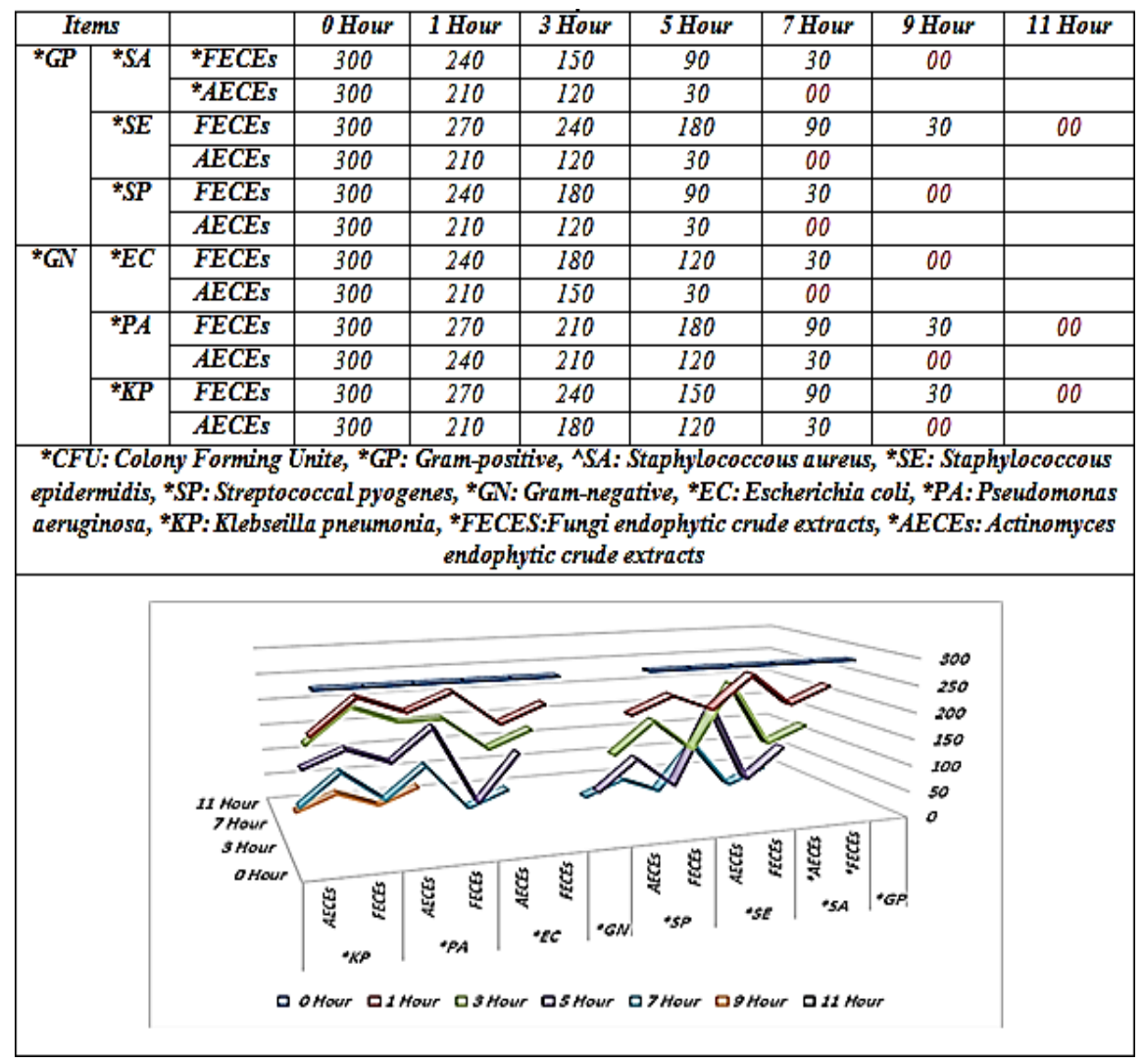


"Habak Al-Madinah Al-Munawarah"; (Ocimum Basilicum) Endophytic-ability against Pathogenicbacteria Proven Success-use-constantly in Saudi-society, Taif, KSA

Table 2 and graph 2 revealed mean of bacterial CFU/ml based on inoculation time, it was found through in-vitro experiment that, the number of growth colonies were more effective by AECEs, because were more powerful than FECEs to kill PB that could lead to infectious diseases in SS [3-13]. The characteristics of $O B$ are a plant that preserves endophytes MOs and kill PB in a very vital biobactericidal way. It is available and cheap price. The results confirm $O B$ proven SUC in SS at HAA, as the use in food and beverages. That because of their medical importance in maintaining PH at HAA [3-13].The present simple research decided endophytes present in OBare of medicinal and therapeutic significance as they included Fungi and Actinomycetes, which secreting substances capable of killing PB by bio-bactericidal way [1-2]. Therefore, that used to adding in drinks and foods in KSA, but the current in-vitro experiment had used at HAA and proved highly effective to kill $\mathrm{PB}$, that might lead to infection. That work which maintained PH and was a sign in proven SUC in SS at HAA, Taif, KSA [1-2].

\section{CONCLuSion}

This present applied effort decided that, $O B$ endophytes MOs showed its bio-bactericidal properties to kill PB. As well, AECEs were stronger than FECEs at HAA.

\section{RECOMMENDATION}

$O B$ recommended using in beverages and foods without boiling to stop killing endophytes MOs and reserved its bio-bactericidal belongings to kill PB. This had established SUC in SS and at HAA, which assistances to uphold $\mathrm{PH}$.

\section{ACKNOWLEDGMENT}

Many thanks directed for all people aided in crop this paper.

\section{REFERENCES}

[1] Tilebeni, G., Review to basil medicinal plant. Int. J. Agronomy and Plant Production, 2011;2(1):5-7.

[2] Alvin, A., Miller, I. and Neilan, A.,Exploring the potential of endophytes from medicinal plants as sources of antimycobacterial compounds. Micro. Res., 2014; 169:483-495.

[3] Stierle, A., Strobel, A. and Eugenia D., Taxol and taxane production by Taxomycesandreanae, an endophytic fungus of Pacic Yew. Science, 1993; 260:214-216.

[4] Alexei, B., Joseph, S. and Olga, F.,Endogenous cardiotonic steroid: Physiology, pharmacology and novel therapeutic targets. Pharm. Rev., 2009; 61:9-38.

[5] Benbott, A., Yahyia, A. andBelaidi, A.,Assessment of the antibacterial activity of crudealkaloids extracted from seeds and roots of the plant Peganumharmala L.J. Nat. Prod. PlantResour.,2012; 2:568-573.

[6] Lei, W., Peng, Q.,Xiu-Feng, L. and Shuai, Z., Comparative analysis of chemical constituents, antimicrobial and antioxidant activities of ethyl acetate extracts of Polygonumcuspidatum and its endophytic Actinomycetes, Streptomyces sp. As 0916. Chi. J. Nat. Med.,2016; 14(2):0117-0123.

[7] Piyamas, A.,Sakon, M.,Eleni, G.,Siraprapa, B. and Patcharee, P., Antibacterial and antioxidant constituents of extracts of endophytic Fungi Isolated from Ocimum basilicum var. thyrsiflora leaves. Curr.Micro.,2017; 74:1185-1193.

[8] Waheeda, K. and Shyam, V., Formulation of novel surface sterilization method and culture media for the isolation of endophytic Actinomycetes from medicinal plants and its antibacterial activity. J. Plant Pathol.Micro.,2017; 8:2-7.

[9] Narendhran, S., Rajiv, P., Vanathi, P. and Rajeshwari, S., Spectroscopic analysis of bioactive compounds from Streptomyces cavouresiskuv39: Evaluation of antioxidant and cytotoxicity activity. Int. J. Pharm. Sci.,2014; 6(7):319-322.

[10] Golinska, P., Wypij, M., Agarkar, G. and Rathod, D., Endophytic Actinobacteriaof medicinal plants: Diversity and bioactivity. Ant. Van. Leeuw., 2015; 108:267-289.

[11] Puri, C., Verma, V., Amna, T., Qazi, N. and Spiteller, J., An endophytic fungus from Nothapodytesfoetida that produces camptothecin. J. Nat. Prod.,2005; 68:1717-1719.

[12] Silva, H., Teles, H., Zanardi, M. and Young, C., Cadinanesesquiterpenoids of Phomopsiscassiae an endophytic fungus associated with Cassia spectabilis (Leguminosae). Phytochemistry, 2007; 67:19691976. 
"Habak Al-Madinah Al-Munawarah"; (Ocimum Basilicum) Endophytic-ability against Pathogenicbacteria Proven Success-use-constantly in Saudi-society, Taif, KSA

[13] Waheeda, K. and Shyam, V., Comparative study of Ocimum basilicum and its endophytic Actinomycetes StreptomycesFlavoviridis A3WK: Evaluation of antioxidant, anti-inflammatory and antimicrobial activity. IJPSR., 2018; 9(3):1023-1034.

[14] Lakshman, C. and Jayshree, K., Diversity of the endophytic fungi isolated from Ocimum basilicum Linn. A Promising Medicinal Plant. PARIPEX, Indian J. Res., 2014; 3(4):204-206.

[15] Dobranic, K., Johanson, A. and Alikhan, R.,.Isolation of endophytic fungi from eastern larch (Larixlancina) leaves from New Brunswick, Canada. Can. J. Micro.,1995; 41(2):194-198.

[16] Tomsheck, R., Strobel, A., Booth, E., Geary, B., Spakowicz, D., Knighton, B., Floerchinger, C., Sears, J., Liarzi, O. and Ezra, D., Hypoxylon sp., an endophyte of Perseaindica, producing 1,8-cineole and other bioactive volatiles with fuel potential. Micro. Ecol., 2010; 60:903-914.

[17] Waheeda, K. and Shyam, V., Formulation of novel surface sterilization method and culture media for the isolation of endophytic Actinomycetes from medicinal plants and its antibacterial activity. J. Plant Pathol.Micro.,2017; 8:2-7.

[18] Lei, W., Peng, Q., Xiu-Feng, L. and Shuai, Z., Comparative analysis of chemical constituents, antimicrobial and antioxidant activities of ethyl acetate extracts of Polygonumcuspidatum and its endophytic Actinomycetes, Streptomyces sp. As 0916. Chi. J. Nat. Med., 2016; 14(2):0117-0123.

[19] Panel-Prem, B., Parajulia-Kyle, R. and Mankinb-Philip, B.,Source specific fecal bacteria modeling using soil and water assessment tool model. Bioresource Technology,2009; 100(2):953-963.

[20] https://quizlet.com/41741253/microbiology-lab-final-study-guide-flash-cards/2019

[21] https://courses.lumenlearning.com/boundless-microbiology/chapter/counting-bacteria/2019

[22] https://people.umass.edu/evagold/excel.html2019

Citation: Sherifa Mostafa M. Sabra \& Afaf Bushara M. Ismail, ""Habak Al-Madinah Al-Munawarah"; (Ocimum Basilicum) Endophytic-ability against Pathogenic-bacteria Proven Success-use-constantly in Saudi-society, Taif, KSA”. International Journal of Research Studies in Biosciences (IJRSB). 7(10), pp. 2630. DOI: http://dx.doi.org/10.20431/2349-4050.0710004

Copyright: (C) 2019 Authors This is an open-access article distributed under the terms of the Creative Commons Attribution License, which permits unrestricted use, distribution, and reproduction in any medium, provided the original author and source are credited. 